\title{
STUDI KEANEKARAGAMAN JENIS-JENIS IKAN DI SUNGAI BATANG PELEPAT KABUPATEN BUNGO PROPINSI JAMBI
}

\author{
Tita Sari $^{{ }^{*}}$ Rini Hertati ${ }^{2}$ Syafrialdi ${ }^{2}$ \\ ${ }^{I}$ Mahasiswa Jurusan Pemanfaatan Sumberdaya Perikanan Fakultas Perikanan, \\ Universitas Muara Bungo-Jambi \\ ${ }^{2}$ Staf Pengajar Jurusan Pemanfaatan Sumberdaya Perikanan Fakultas Perikanan, \\ Universitas Muara Bungo-Jambi \\ *Email: rinihertati4@gmail.com
}

\begin{abstract}
ABSTRAK
Keanekaragaman sumberdaya perikanan memiliki potensi yang besar, namun rentan terhadap aktifitas antropogenik (aktivitas manusia) dan penangkapan ikan secara besar-besaran. Penelitian ini bertujuan untuk mengetahui jenis-jenis ikan yang tertangkap di Sungai Batang Pelepat Kabupaten Bungo Provinsi Jambi dan mengetahui tingkat indeks keanekaragaman jenis ikan, Indeks keseragaman dan indeks dominasi. Penelitian ini dilakukan pada bulan Mei-Juli 2019 di Sungai Batang Pelepat Kabupaten Bungo Provinsi Jambi. Hasil penelitian menunjukan bahwa ikan yang tertangkap berjumlah 120 ekor, terdiri dari 9 jenis yang mewakili 3 famili. Indeks keanekaragaman tertinggi di jumpai pada Stasiun III dengan nilai 2,11 serta terendah terdapat pada Stasiun I dengan nilai sebesar 2,07. Nilai indeks dominansi tertinggi terdapat pada stasiun 1 dan II dengan masingmasing nilai 0,29 dan terendah terdapat pada stasiun III dengan nilai 0,23. Nilai indeks keseragaman tertinggi terdapat pada stasiun III dengan nilai 0,91 dan terendah ditemukan pada stasiun I dan stasiun II dimana nilai masing-masing yaitu 0,90 .
\end{abstract}

Kata Kunci: Keanekaragaman, Jenis Ikan, Sungai Batang Pelepat, Muara Bungo

\section{PENDAHULUAN}

\section{Latar Belakang}

Salah Satu Sungai yang terdapat di Kabupaten Bungo yaitu Sungai Batang Pelepat. Sungai Batang Pelepat ini banyak dimanfaatkan oleh beberapa sektor seperti: pertanian, perikanan, pertambangan, perhubungan dan juga merupakan sumber air minum masyarakat. Adanya berbagai aktifitas masyarakat disekitar perairan Sungai Batang Pelepat akan memberikan dampak yang negatif terhadap ekosistem perairan Sungai Batang Pelepat sehingga Sungai Batang Pelepat akan mengalami perubahan-perubahan ekologis dimana kondisinya sudah berbeda dengan kondisi alami yang semula (Mahyudi et al., 2017). Keanekaragaman ikan dapat dikatakan baik apabila keberadaannya yang tinggi disuatu perairan, hal itu menunjukan keadaan komunitas baik, sebaliknya keanekaragaman yang kecil berarti telah terjadi ketidak seimbangan 
ekologis diperairan tersebut (Koesbiono, 1989).

Keanekaragaman jenis ikan di Indonesia cukup tinggi. Ikan yang hidup di perairan Indonesia ada lebih dari 4.000 jenis, dan 800 jenis diantaranya hidup di air tawar dan payau (Sagala et al., 2014). Perairan umum air tawar alami dikenal sebagai sungai, rawa dan danau. Perairan sungai merupakan suatu perairan yang didalamnya dicirikan dengan adanya aliran air yang cukup kuat, sehingga digolongkan ke dalam perairan mengalir (perairan lotik) (Budiyono, 2011). Sungai sebagai salah satu bentuk ekosistem lotik (perairan mengalir) berfungsi sebagai media atau tempat hidup organisme makro maupun mikro, baik itu yang menetap maupun yang dapat berpindah-pindah (Maryono, 2005). Menurut Kholis et al., (2018) pengelolaan perikanan saat ini perlu memperhatikan aspek biologi untuk keberlanjutan usaha penangkapan dan kelestariannya, seperti kasus ikan kurau di Kabupaten Bengkalis Provinsi Riau yang produksinya terus mengalami penurunan. Oleh karena itu melalui penelitian ini diharapkan dapat menggambarkan bagaimana keanekaragaman dan biologis ikan yang ada di Sungai Batang Pelepat dengan melihat kondisinya saat ini. Penelitian ini bertujuan untuk mengetahui jenis-jenis ikan yang tertangkap di Batang Pelepat Kabupaten Bungo Provinsi Jambi dan mengetahui tingkat indeks keanekaragaman jenis ikan, indeks keseragaman dan indeks dominasi.

\section{METODE PENELITIAN}

\section{Waktu dan Tempat}

Penelitian ini dilakukan pada di Sungai Batang Pelepat (Gambar $1)$.

bulan Mei sampai dengan Juli 2019

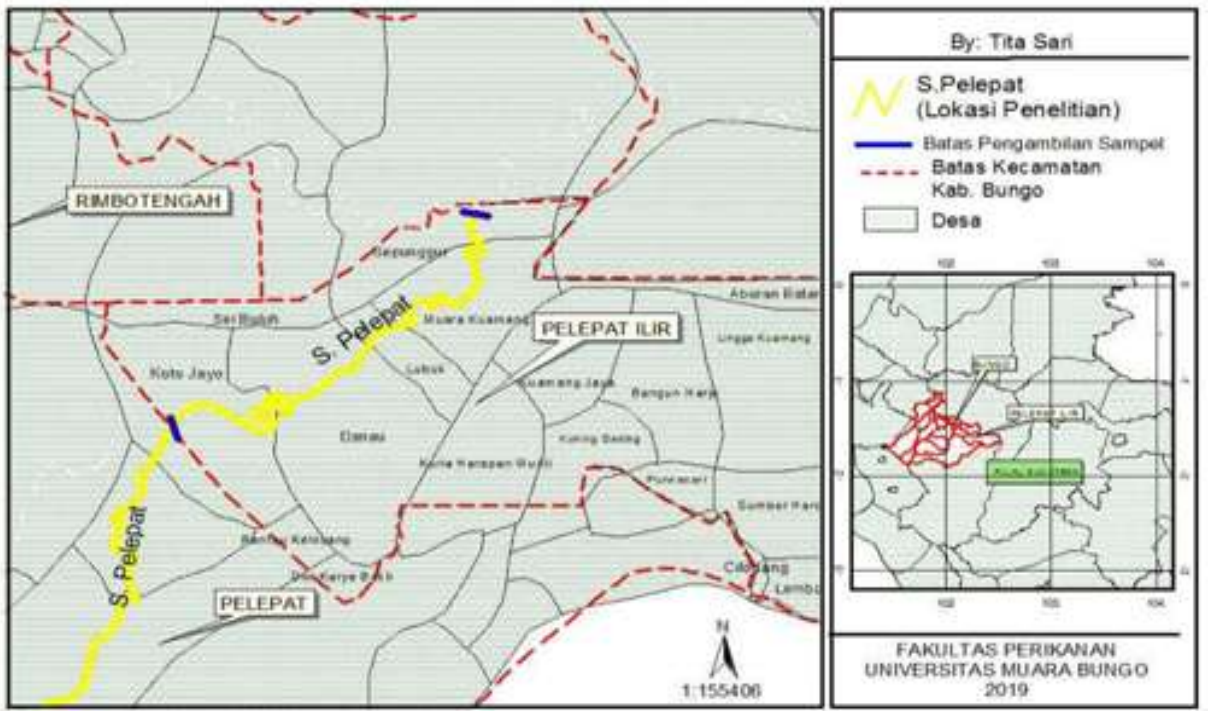

Gambar 1. Peta lokasi Penelitian

\section{Sumber dan Teknik Pengumpulan Data}

Metode yang digunakan pada penelitian ini adalah metode survei dengan melakukan pengamatan dan observasi secara langsung ke lapangan dengan teknik wawancara secara purposive sampling. Sumber data hanya menggunakan data primer dan didukung data sekunder. 
Metode pengumpulan data dilakukan dengan menentukan stasiun pengamatan melalui purposive sampling merujuk hasil studi pendahuluan yaitu mewakili satu daerah aliran sungai utama yang menjadi tiga bagian yaitu Hulu, Tengah dan Hilir. Daerah Hilir merupakan daerah terdekat dengan tempat yang sering digunakan masyarakat dalam memenuhi kebutuhan sehari-hari seperti: penangkapan ikan, dan pergi kekebun. Sedangkan daerah hulu merupakan tempat terjauh dari permukiman masyarakat dan terdapat sebagian kecil aktivitas masyarakat.

Populasi dalam penelitian ini adalah semua jenis ikan yang tertangkap di Sungai Batang Pelepat. Sedangkan sampel dalam penelitian ini adalah perwakilan setiap jenis

\section{Bahan dan Alat}

Peralatan yang digunakan untuk penelitian ini yaitu : alat tulis, timbangan elektrik, alat untuk menangkap sampel ikan digunakan alat tangkap jaring insang berukuran panjang $\pm 30 \mathrm{~m}$, tinggi $1 \mathrm{~m}$ dengan ukuran masing-masing mata jaring $0,5,0,75$ dan 1 inchi, jala tebar

\section{Analisis Data}

1. Analisis Indeks Keanekaragaman Jenis Ikan (Hi)

Indeks keanekaragaman (H') merupakan gambaran kekayaan spesies ikan yang dapat dilihat dari kehadiran jumlah spesies dalam

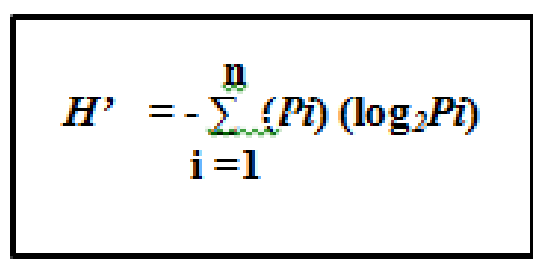

Keterangan :

Dimana : ikan yang tertangkap di hulu, pertengahan dan hilir, atau tiap-tiap Stasiun. Dalam melakukan penangkapan ini penulis melakukan 2 kali untuk 1 stasiun dengan 3 kali ulangan setiap harinya dengan luas areal penangkapan masing-masing stasiun dengan panjang $100 \mathrm{~m}$ dengan lebar $40 \mathrm{~m}^{2}$. Penggunaan alat tangkap jala tebar dioperasikan pada bagian tengah sungai yang memiliki kecepatan arus yang relatif tinggi selama kurang lebih 1 jam disetiap satasiun, sedangkan jaring insang ( gill net) dioperasikan pada perairan dalam (lubuk) selama 6 jam dan diangkat 2 jam sekali dengan jarak tiap jaring $\pm 50 \mathrm{~m}$. Untuk tepi perairan yang tertutup vegetasi dilakukan penangkapan menggunakan alat pancing tajur.

dengan ukuran $3 \mathrm{~m}$, tinggi $2 \mathrm{~m}$, ukuran mata jaring 0,5 inchi, pancing/tajur dengan jumlah sebanyak 50 buah, penggaris, handphone serta perahu. Sedangkan bahan yang digunakan adalah sampel ikan, formalin, alkohol dan es batu untuk menyimpan sampel agar tetap segar sampai ke lokasi pengamatan.

suatu komunitas dengan kelimpahan relatif (jumlah individu tiap spesies). Indeks keragaman yang paling umum digunakan adalah indeks menurut Shannon-Wiener (Brower \& Zar, 1990), dilambangkan dengan (H') yang dibatasi sebagai :

H' = Indeks Keanekaragaman (Shannon-Wienner).

$\mathrm{Pi} \quad=$ Perbandingan antara jumlah individu spesies ikan ke-i dengan jumlah total individu ikan (jumlah individu spesies $\mathrm{ke}-\mathrm{i}, \mathrm{Pi}=\mathrm{ni} / \mathrm{N}$ ni = Jumlah individu jenis ke-i. $\mathrm{N} \quad=$ Jumlah total spesies. 
Menurut Preniti et al., (2019) penentuan kriteria indeks keanekaragaman yaitu $\quad \mathrm{H}^{\prime}<1$ samadengan keanekaragaman

\section{Indeks Keseragaman (E)} Indeks (E ) individu tiap spesies yang terdapat pada suatu perairan dapat ditentukan dengan indeks keseragaman yaitu :

$$
E=\frac{H^{\prime}}{H^{l} \max }=\frac{H^{\prime}}{\log _{2} \mathrm{~s}}
$$

3. Indeks Dominasi (D)

Penentuan jenis ikan yang dominan didalam kawasan penelitian, ditentukan dengan menggunakan rumus berikut :

$$
D=\frac{n i}{N} \times 100 \%
$$

4. Kepadatan Populasi, Kepadatan Relatif dan Frekuensi Kehadiran Menghitung

Kepadatan Populasi (KP), Kepadatan Relatif (KR) dan Frekuensi Kehadiran (FK) menggunakan persamaan sebagai berikut:

a. Kepadatan Populasi (KP)

$\mathrm{KP}\left(\right.$ indv $\left./ \mathrm{m}^{2}\right)=\underline{\text { Jumlah Individu }}$

Suatu jenis

Luas Area / Plot

b. Kepadatan Relatif (KR) rendah, jika $1<\mathrm{H}^{\prime}<3$ sama dengan keanekaragaman sedang dan jika $\mathrm{H}^{\prime}>3$ keanekaragaman tinggi.

Keterangan :

$\mathrm{H}^{\prime}=$ Indeks Keanekaragaman Shannon-Weiner

$\mathrm{H}^{\prime} \max =$ Keanekaragaman species maksimum

$\mathrm{E}=0$, terdapat dominasi Spesies atau semakin kecil keseragaman

$\mathrm{E}=1$, Jumlah Individu tiap spesies sama atau seragam

Keterangan :

$\mathrm{D}=$ Indeks dominansi suatu jenis ikan

$\mathrm{N}=$ jumlah individu suatu jenis

$\mathrm{N}=$ jumlah individu dari seluruh jenis

Kriteria :

$\mathrm{Di}=0-2 \%$ jenis tidak dominan

$\mathrm{D}=2-5 \%$ jenis sub dominan

$\mathrm{D}=>5 \%$ jenis dominan

$$
\text { KR }(\%)=\text { Kepadatan Suatu Jenis }
$$$$
\text { X } 100 \%
$$
Jumlah

Kepadatan Seluruh Jenis

c. Frekuensi Kehadiran (FK)

$\mathrm{FK}=\underline{\text { Jumlah Plot yang ditempati }}$ Suatu Jenis X $100 \%$

Jumlah Total plot

Di mana:

FK $=0-25 \% \quad: \quad$ Kehadiran sangat jarang

FK $=25-50 \%:$ Kehadiran jarang

FK $=50-75 \%:$ Kehadiran sedang

FK $>75 \%$ : $\quad$ Kehadiran sering/absolut. 


\section{HASIL DAN PEMBAHASAN \\ Jenis-Jenis Ikan yang Tertangkap di Tiga Stasiun Pengamatan}

Jenis ikan yang tertangkap di tiga stasiun dalam pengamatan yang paling banyak tertangkap yaitu terdiri dari (Osteochilus hasselti) famili Cyprinidae dan Mickrophis brachurus dari famili
Mastacenbeidae dan yang paling sedikit Oxyeleotris marmorata dari famili Eleotridae dan ikan gurame (Osphronemus gouramy) dari famili Anabantidae. Untuk lebih jelasnya dapat disajikan pada (Tabel 1).

Tabel1. Jenis-jenis ikan yang tertangkap dan taksonominya di Tiga Stasiun Sungai Batang Pelepat Kabupaten Bungo

\begin{tabular}{|c|c|c|c|c|c|c|c|}
\hline No & Filum & Ordo & Famili & Genus & Spesies & $\begin{array}{c}\text { Nama } \\
\text { Daerah }\end{array}$ & $\begin{array}{c}\text { Jumlah } \\
\text { Ekor } \\
\text { (ekor) }\end{array}$ \\
\hline \multirow{2}{*}{1} & \multirow{2}{*}{ Chordata } & \multirow{3}{*}{ Ostariophysi } & \multirow{2}{*}{ Bagridae } & Macrones & $\begin{array}{c}\text { Mystus } \\
\text { nemurus }\end{array}$ & Baung & 13 \\
\hline & & & & Macrones & $\begin{array}{c}\text { Makrones } \\
\text { mikrocanthus }\end{array}$ & Singgiring & 14 \\
\hline \multirow[t]{2}{*}{2} & Chordata & & Pangasidae & Cryptopterus & $\begin{array}{l}\text { Criptopterus } \\
\quad \text { limpok }\end{array}$ & Lais & 16 \\
\hline & & & & Thynnicthys & $\begin{array}{l}\text { Thinnicthys } \\
\text { thynnoides }\end{array}$ & Lambak & 11 \\
\hline \multirow[t]{2}{*}{3} & Chordata & & Cyprinidae & Osteochilus & $\begin{array}{c}\text { Osteochilus } \\
\text { hasselti }\end{array}$ & Palau & 17 \\
\hline & & & & Puntius & $\begin{array}{c}\text { Puntius } \\
\text { schwanefeldi }\end{array}$ & Lampam & 8 \\
\hline 4 & Chordata & Synbranchiformes & Mastacenbeidae & Microphis & $\begin{array}{c}\text { Mickrophis } \\
\text { brachurus }\end{array}$ & Tilan & 17 \\
\hline \multirow[t]{2}{*}{5} & Chordata & \multirow[t]{3}{*}{ Perciformes } & Ngndidae & Pristolepis & $\begin{array}{c}\text { Pristolepis } \\
\text { grooti }\end{array}$ & Batung & 12 \\
\hline & & & Eleotridae & Oxyeleotris & $\begin{array}{l}\text { Oxyeleotris } \\
\text { marmorata }\end{array}$ & Betutu & 5 \\
\hline \multirow[t]{2}{*}{6} & Chordata & & Anabantidae & $\begin{array}{c}\text { Osphronemu } \\
s\end{array}$ & $\begin{array}{c}\text { Osphronemu } \\
\text { s gouramy }\end{array}$ & Gurami & 7 \\
\hline & \multicolumn{4}{|c|}{ Total Individu } & & & 120 \\
\hline
\end{tabular}

Tabel 1 menjelaskan bahwa jenis ikan terbanyak di tiga stasiun pengamatan Sungai Batang Pelepat terdiri dari famili Cyprinidae (3 jenis), Bagridae (2 jenis). Banyaknya jenis ikan dari famili Cyprinidae yang tertangkap di tiga stasiun Sungai Batang Pelepat ini berhubungan erat dengan keadaan sungai Batang Pelepat yaitu pada stasiun I yang merupakan daerah dekat dengan aliran anak sungai batang Senamat, sehingga sungai mengalami perombakan air sehingga memperbaiki kualitas air melalui fenomena pertemuan 2 aliran air sungai. Meskipun stasiun ini memiliki warna air yang keruh dan subtrat dasarnya berlumpur bepasir. Perbedaan komposisi jenis ikan antara musim air dalam dengan musim air dangkal disebabkan adanya migrasi ikan dari rawa-rawa ke sungai atau sebaliknya. Perubahan musim mengakibatkan perubahan kualitas air (Hidayati, 2015). Perubahan kualitas air mengakibatkan ikan yang tidak dapat mentoleransi kondisi tersebut akan melakukan migrasi. Perubahan 
kedalaman air juga merupakan perangsang ikan melakukan migrasi untuk bereproduksi maupun mencari makanan (Hidayati, 2015).

Keberadaan ikan di suatu tempat tidak terlepas dari kondisi habitat sebagai penyedia sumberdaya bagi kebutuhan hidup ikan. Adanya variasi kondisi habitat menyebabkan ikan harus berinteraksi termasuk beradaptasi dengan habitatnya. Bentuk adaptasi ikan terhadap habitat antara lain adaptasi morfologi pada tipe letak mulut, tipe gigi rahang bawah dan bentuk sirip ekor. Tipe letak mulut, tipe gigi rahang bawah dan bentuk sirip ekor menunjukan

\section{Keanekaragaman Jenis-Jenis Ikan di Sungai Batang Pelepat}

Selama penelitian dilakukan, ikan yang berhasil tertangkap berjumlah 120 ekor, terdiri dari 10 adaptasi ikan terkait dengan sumberdaya makanan dan cara memperolehnya (guild). Pengelompokan ikan berdasarkan cara memperoleh makanan (guild) telah dikenal yaitu herbivora endogenus (pemakan lumut dan alga), herbivora eksogenus (pemakan buah,daun dan biji yang jatuh ke sungai), karnivora pemakan binatang kecil (pemakan plakton, nematoda dan rotifera), karnivora pemakan serangga, karnivora pemakan ikan lain dan omnivora (Kottelat et al., 1993).

jenis yang mewakili 3 Ordo, 7 Famili dan 10 Genus, (Tabel 2). Jumlah di tiga stasiun pengamatan masing-masing lebih jelas dapat dilihat pada Tabel 2.

Tabel 2. Keanekaragaman Jenis Ikan di Sungai Batang Pelepat Kabupaten Bungo

\begin{tabular}{|c|c|c|c|c|c|c|}
\hline \multirow{2}{*}{ No } & \multirow{2}{*}{ Genus/Species } & \multirow{2}{*}{$\begin{array}{l}\text { Nama } \\
\text { Daerah }\end{array}$} & \multicolumn{3}{|c|}{ Stasiun } & \multirow{2}{*}{ Total } \\
\hline & & & 1 & 2 & 3 & \\
\hline \multirow[t]{3}{*}{1} & Bagridae & & & & & \\
\hline & Mystus nemurus & Baung & 6 & 3 & 4 & 13 \\
\hline & $\begin{array}{l}\text { Macrones nigriceps } \\
\text { Pangasidae }\end{array}$ & Singgiring & 5 & 6 & 3 & 14 \\
\hline 2 & Criptopterus limpok & Lais & 7 & 4 & 5 & 16 \\
\hline \multirow{4}{*}{3} & Cyprinidae & & & & & \\
\hline & Thinnicthys thynnoides & Lambak & 2 & 8 & 1 & 11 \\
\hline & Osteochilus hasselti & Palau & 8 & 2 & 7 & 17 \\
\hline & Puntius schwanefeldi & Lampam & 2 & 3 & 3 & 8 \\
\hline 4 & $\begin{array}{l}\text { Mastacenbeidae } \\
\quad \text { Mickrophis brachurus }\end{array}$ & Tilan & 8 & 5 & 4 & 17 \\
\hline \multirow[t]{2}{*}{5} & Ngndidae & & & & & \\
\hline & Pristolepis grooti & Batung & - & 5 & 7 & 12 \\
\hline 6 & $\begin{array}{l}\text { Anabantidae } \\
\text { Osphronemus gouramy }\end{array}$ & Gurame & 6 & - & 1 & 7 \\
\hline \multirow[t]{4}{*}{7} & $\begin{array}{l}\text { Eleotridae } \\
\quad \text { Oxyeleotris marmorata }\end{array}$ & Betutu & 2 & 2 & 1 & 5 \\
\hline & Total Individu & & 46 & 38 & 36 & 120 \\
\hline & Total Spesies & & 9 & 9 & 10 & 28 \\
\hline & Total Genus & & 6 & 6 & 7 & 19 \\
\hline
\end{tabular}


Hasil pengamatan menunjukkan adanya keragaman jenis ikan yang ditertangkap di Sungai Batang Pelepat. Stasiun I (Dusun Koto Jayo) tercatat ada 9 spesies dan 6 genus dari jumlah total individu yang ditemukan sebanyak 46 ekor. Stasiun II (Dusun Danau) ditemukan 9 Spesies dan 6 genus dari total individu yang ditemukan sebanyak 38 ekor, di stasiun III (Dusun Padang Palangeh) ditemukan 10 Spesies dan 7 genus dari 36 ekor ikan.

Berdasarkan hasil Penelitian Kasmawati et al., (2018) penelitian di Sungai Batang Bungo ditemukan sebanyak 156 ekor, terdiri dari 16 jenis yang mewakili 5 Ordo, 9 Famili dan 15 Genus dan hasil analisis indeks keanekaragaman jenis menunjukkan indeks keanekaragaman berkisar antara 0,58 hingga 1,46 Indeks keanekaragaman tertinggi di jumpai di Stasiun I Dusun Buat, Stasiun III Kelurahan Sungai Pinang, dan terendah terdapat pada Stasiun II di Dusun Tebat. Kepadatan Populasi (KP) tertinggi dari tiga stasiun yaitu, Tilan (Microphis brachyurus) sebesar 0.0042 (individu) $/ \mathrm{m}^{2}$, Kepadatan Relatif (KR) tertinggi terapat pada Tilan (Mastcembetus unicdar), Seluang (Rasbora argyrotaenia), sedangkan untuk Frekuensi Kehadiran (FK) tertinggi yaitu Tilan (Microphis brachyurus), Lampam (Puntius schwanepeldi), Lais (Criptopterus limpok), Gurami (Osphronemus gouramy), Baung (Mystus nemurus) masing-masing $100 \%$.

Jenis ikan terbanyak di perairan Sungai Batang Pelepat terdiri dari famili Cyprinidae (3 jenis), dan Bagridae (2 jenis). Menurut Kottelat et al., (1993) bahwa jenis ikan Cyprinidae merupakan penghuni utama yang paling besar jumlah populasinya untuk beberapa Sungai di Propinsi Jambi selain jenis Bagridae. Tingginya jenis ikan dari famili Cyprinidae pada stasiun I dikarenakan pada stasiun I terdapat aliran anak sungai Batang Senamat yang mengalir ke Sungai Batang Pelepat sehingga terjadi perombakan air serta pada stasiun satu juga terdapat batang-batang kayu mati dialiran sungai bagian pinggir sehingga kondisi tersebut dimanfaatkan sebagai tempat perlindungan dari pemangsa dan sebagai tempat ikan mencari makan.

Total jumlah ikan yang didapat Sungai Batang Pelepat paling banyak ditemukan adalah jenis Microphis brachyurus sebanyak 17 ekor, diikuti oleh Osteochilus hasselti sebanyak 17 ekor, Criptopterus limpok sebanyak 16 ekor, Makrones mikrocanthus sebanyak 14 ekor, Mystus nemurus sebanyak 13 ekor, Pristolepis grooti 11 ekor dan Thinnicthys thynnoides sebanyak 11 ekor. Sedangkan jumlah total ikan paling sedikit adalah jenis ikan Osphronemus gouramy hanya 7 ekor dan Oxyeleotris marmorata sebanyak 5 ekor. Jumlah total ikan berhubungan dengan kehadiran jenis ikan disetiap stasiun pengamatan. Kehadiran jenis berpengaruh terhadap jumlah jenis, individu, famili dan mempengaruhi pula dengan nilai keanekaragaman, kemerataan serta dominansi pada setiap stasiun (Magurran, 1988); (2013). 
Indeks Keanekaragaman, Dominasi dan Keseragaman

1. Indeks Keanekaragaman Hasil analisis indeks keanekaragaman jenis menunjukkan indeks keanekaragaman berkisar antara 2,07 hingga 2,11. Indeks keanekaragaman tertinggi di jumpai di Stasiun III Dusun Padang Palangeh (Tabel 3).

Tabel 3. Jumlah Jenis, Individu, Famili, Indeks Keanekaragam Jenis Ikan di Sungai Batang Pelepat

\begin{tabular}{lccccc}
\hline \multirow{2}{*}{\multicolumn{1}{c}{ Keterangan }} & \multicolumn{3}{c}{ Jumlah } & \multirow{2}{*}{ Total } \\
\cline { 2 - 3 } & ST I & & ST II & ST III & \\
\cline { 1 - 3 } Jumlah Jenis & 9 & 9 & 10 & $\mathbf{1 0}$ \\
Jumlah Famili & 6 & 6 & 7 & $\mathbf{7}$ \\
Jumlah Induvidu & 46 & 38 & 36 & $\mathbf{1 2 0}$ \\
Indeks Keanekaragaman Jenis & $\mathbf{2 , 0 7}$ & $\mathbf{2 , 0 8}$ & $\mathbf{2 , 1 1}$ & $\mathbf{2 , 2 4}$ \\
\hline
\end{tabular}

Tabel 3 menunjukkan bahwa rata-rata indeks keanekargaman jenis ikan di Sungai Batang Pelepat Kabupaten Bungo dari ke 3 stasiun sebesar 2,24 termasuk dalam kategori sedang. Selanjutnya menurut Magurran (1988); (2013) menyatakan bahwa keanekaragaman tinggi apabila nilai indeks keanekaragaman $\left(\mathrm{H}^{\prime}\right) \quad>3$; sedang $1<\mathrm{H}^{\prime}<3$ dan rendah jika $\mathrm{H}^{\prime}<1$. Semakin tinggi $\mathrm{H}^{\prime}$ mengindikasikan semakin tinggi jumlah spesies dan kelimpahan relatifnya, ditunjukan pada stasiun III (Dusun Padang Palangeh) yang mempunyai jumlah spesies cukup tinggi (10 jenis) sehingga nilai indeks keanekaragaman (H') sebesar 2,11 atau $\left(\mathrm{H}^{\prime}\right)<3$. Indeks keanekaragaman

Stasiun III (Dusun Padang Palangeh) yang tinggi berhubungan dengan luas dan kedalaman sungai. Area yang lebih luas sering memiliki variasi habitat yang lebih besar dibandingkan dengan area yang lebih sempit, sehingga semakin panjang dan lebar ukuran sungai semakin banyak pula jumlah ikan yang menempatinya (Kottelat et al., 1993).
Adanya hubungan positif antara kekayaan jenis dengan suatu area yang ditempati berhubungan pula dengan keanekaragaman jenis ikan. Stasiun III juga merupakan daerah yang dekat dengan aliran anak sungai yang mengalami perombakan air sehingga memperbaiki kualitas air melalui fenomena pertemuan 2 aliran air sungai. Selain faktor di atas, kemampuan dalam mencari makan juga mempengaruhi kelimpahan jenis ikan. Jenis ikan (Cyprinidae) memiliki semacam mulut yang berfungsi dalam mendeteksi sumber makanan. Jenis ikan ini, umumnya memiliki tipe mulut superior yang memungkinkan ikan mendapatkan makanan di dasar sungai (Hui, 2009).

Kebiasaan makan ikan dipengaruhi oleh berbagai faktor penting yaitu kondisi habitat, kesukaan terhadap jenis makanan tertentu, ukuran dan umur ikan. Perubahan kondisi lingkungan juga mempengaruhi perubahan persediaan makanan dan akan merubah perilaku makan ikan (Zahid \& Rahardjo, 2008). Famili Cyprinidae mempu hidup baik pada daerah sungai yang memiliki arus kuat maupun arus 
lemah dengan kualitas air yang baik (Wahyuni et al., 2018). Keberadaan ikan di suatu tempat tidak terlepas dari kondisi habitat sebagai penyedia makanan bagi kebutuhan hidup ikan. Adanya variasi kondisi habitat menyebabkan ikan harus berinteraksi termasuk beradaptasi dengan habitatnya. Bentuk adaptasi ikan terhadap habitat antara lain adaptasi morfologi pada tipe letak mulut, tipe gigi rahang bawah dan bentuk sirip ekor.

2. Indeks Dominasi (D)

Indeks Dominansi (D) di 3

Stasiun titik pengambilan sampel berada pada kategori berkisar antara 0,23 sampai 0,29. Berdasarkan (Tabel 4) menunjukkan bahwa dari semua stasiun pengambilan sampel, Stasiun I dan Stasiun II dijumpai tingkat dominansi tertinggi dibandingkan dengan Stasiun III. Semakin ke hulu indeks dominasi semakin tinggi, dimana semakin kecil nilai indeks dominansi maka menunjukan bahwa tidak ada spesies yang mendominsi sebaliknya semakin besar dominansi maka menunjukkan ada spesies tertentu (Odum, 1993).

Tabel 4. Hasil Perhitungan Indeks Dominasi (D) di Tiga Stasiun penelitian Sungai Batang Pelepat

\begin{tabular}{|c|c|c|c|c|c|c|}
\hline No & Famili & Spesies & Jumlah & STI & ST2 & ST3 \\
\hline 1 & Bagridae & Mystus nemurus & 13 & 0.00657414 & 0.00657414 & 0.01234568 \\
\hline 2 & Bagridae & Makrones mikrocanthus & 14 & 0.02629657 & 0.02629657 & 0.00694444 \\
\hline 3 & Pangasidae & Criptopterus limpok & 16 & 0.01168736 & 0.01168736 & 0.01929012 \\
\hline 4 & Cyprinidae & Thinnicthys thynnoides & 11 & 0.04674945 & 0.04674945 & 0.0007716 \\
\hline 5 & Cyprinidae & Osteochilus hasselti & 17 & 0.00292184 & 0.00292184 & 0.03780864 \\
\hline 6 & Cyprinidae & Puntius schwanefeldi & 8 & 0.00292184 & 0.00292184 & 0.00694444 \\
\hline 7 & Mastacenbeidae & Mickrophis brachurus & 17 & 0.0182615 & 0.0182615 & 0.01234568 \\
\hline 8 & Ngndidae & Pristolepis grooti & 12 & 0.0182615 & 0.0182615 & 0.03780864 \\
\hline 9 & Eleotridae & Oxyeleotris marmorata & 5 & 0 & 0 & 0.0007716 \\
\hline \multirow[t]{2}{*}{10} & Anabantidae & Osphronemus gourami & 7 & 0.15771734 & 0.15771734 & 0.09954219 \\
\hline & & & 120 & 0,29139154 & 0,29139154 & 0.23457306 \\
\hline
\end{tabular}

\section{Indes keseragaman (E)}

Nilai Indeks Keseragaman (E') terendah ditemukan pada stasiun dusun Koto Jayo) dimana nilai E' yaitu 0,90, pada stasiu II (Dusun Danau) yaitu 0,90 dan pada stasiun III (Dusun Padang Panglangeh) sebesar 0,91. Sesuai dengan Kisaran indeks keseragaman (Magurran, 2013) menyatakan sebaran individu antar jenis tidak merata/ada jenis tertentu yang dominan. Hal ini juga berkorelasi dengan rendahnya Indeks Keanekaragaman (H') pada stasiun ini. Tabel 3 menunjukan semakin tinggi indeks Keanekaragaman ( $\left.\mathrm{H}^{\prime}\right)$ maka Indeks Keseragaman (E') semakin mendekati 0 (nol). Adanya perbedaan nilai indeks keanekaragaman dan keseragaman yang bervariasi pada perairan menurut Yazwar (2008), disebabkan oleh faktor fisika air serta ketersediaan nutrisi dan pemanfaatan 
nutrisi yang berbeda dari tiap individu. Ketersediaan makanan serta kemampuan dari masing-masing jenis ikan untuk beradaptasi dengan lingkungan yang ada.

4. Kepadatan Populasi, Kepadatan Relatif dan Frekuensi Kehadiran
Berdasarkan hasil sampel ikan yang tertangkap pada saat penelitian didapatkan hasil perhitungan Kepadatan Populasi, Kepadatan Relatif, dan Frekuensi Kehadiran pada Tabel 5.

Tabel 5. Hasil Perhitungan Kepadatan Populasi, Kepadatan Relatif, dan Frekuensi Kehadiran

\begin{tabular}{|c|c|c|c|c|}
\hline No & Jenis Ikan & $\mathrm{KP}$ & KR & FK \\
\hline 1 & Mystus nemurus & 0,0032 & 10,833 & 75.00 \\
\hline 2 & Makrones mikrocanthus & 0,0035 & 11,666 & 100,00 \\
\hline 3 & Criptopterus limpok & 0,0040 & 13,333 & 100,00 \\
\hline 4 & Thinnicthys thynnoides & 0,0027 & 9,1666 & 60.00 \\
\hline 5 & Osteochilus hasselti & 0,0042 & 14,166 & 100.00 \\
\hline 6 & Puntius schwanefeldi & 0,0020 & 6,666 & 50,00 \\
\hline 7 & Mickrophis brachurus & 0,0042 & 14,166 & 100.00 \\
\hline 8 & Pristolepis grooti & 0,0030 & 10,00 & 75.00 \\
\hline 9 & Oxyeleotris marmorata & 0,0012 & 4,1666 & 50,00 \\
\hline 10 & Osphronemus gouramy & 0,0017 & 5,8333 & 60,00 \\
\hline & Total & $\mathbf{0 , 0 2 9 7}$ & & $77,00 \%$ \\
\hline
\end{tabular}

Tabel 5 diatas menjelaskan bahwa Kepadatan Populasi (KP) tertinggi ditemukan pada jenis Ikan Microphis brachyurus sebesar 0.0042 (individu $/ \mathrm{m}^{2}$ ), Osteochilus hasselti $\quad 0,0042 \quad$ (individu $/ \mathrm{m}^{2}$ ), Makrones mikrocanthus 0,0035 (individu $/ \mathrm{m}^{2}$ ), Mystus nemurus sebesar 0,0032 (individu $/ \mathrm{m}^{2}$ ), Pristolepis grooti sebesar $\quad 0,0030$ (individu $/ \mathrm{m}^{2}$ ). Hal ini di duga karena kualitas air yang baik serta jenis-jenis ikan ini memiliki kemampuan dalam mencari makanan. Hal ini sesuai dengan pendapat Gonawi (2009) jenis-jenis tersebut memiliki kelimpahan tertinggi karena memiliki kemampuan dalam beradaptasi dan dapat memanfaatkan potensi sumberdaya yang ada untuk mencukupi hidup. Untuk Kepadatan Relatif (KR) tertinggi terdapat pada ikan Mickrophis brachurus sebesar $14,166 \%$ dan Osteochilus hasselti $14,166 \%$. Sedangkan Kepadatan Relatif (KR) yang rendah di temukan terdapat pada ikan Oxyeleotris marmorata, 4,1666 \%. Sedangkan untuk Frekuensi Kehadiran (FK) 
tertinggi ditemukan pada ikan Makrones mikrocanthus, Criptopterus limpok, Microphis brachyurus, Osteochilus hasselti masing-masing 100\% . Sedangkan Frekuensi Kehadiran (FK) terendah ditemukan pada ikan Puntius schwanefeldi, Oxyeleotris marmorata masing-masing 50,00\%.

\section{KESIMPULAN DAN SARAN}

\section{Kesimpulan}

Hasil dari penelitian ini dapat disimpulkan bahwa ikan yang tertangkap berjumlah 120 ekor, terdiri dari 9 jenis yang mewakili 3 famili. Indeks keanekaragaman tertinggi di jumpai pada Stasiun III dengan 2,11 serta terendah terdapat pada Stasiun I dengan nilai sebesar 2,07. Nilai Indeks Dominansi tertinggi terdapat pada stasiun 1 dan II dengan masing-masing nilai 0,29 dan terendah terdapat pada stasiun III dengan nilai 0,23. Nilai Indeks Keseragaman tertinggi terdapat pada stasiun III dengan nilai 0,91 dan terendah ditemukan pada stasiun I

\section{DAFTAR PUSTAKA}

Brower, J. E., Zar, J. H., \& Von Ende, C. N. (1990). Field and laboratory methods for general ecology 3rd ed. Wm.

Budiyono, 2011. Analisis Pengaruh Penambangan Emas dan Pasir Terhadap Kualitas Air dan Keanekaragaman Jenis Ikan di Sungai Batang Bungo Kabupaten Bungo., Tesis Pasca Sarjana Universitas Bung Hatta. Padang.

Gonawi, G. R. (2009). Habitat Struktur Komunitas Nekton Di Sungai Cihideung-Bogor Jawa
Berdasarkan Kriteria penilaian keanekaragaman jenis ShannonWienner, maka Frekuensi Kehadiran (FK\%) Jenis Ikan di Sungai Batang Pelepat Kabupaten Bungo Propinsi Jambi dapat dikatakan dengan kehadiran tinggi yaitu 77,00 \% .

dan stasiun II dimana nilai masingmasing yaitu 0,90 .

\section{Saran}

Sebagai saran pada penelitian ini diharapkan dilakukan penelitian lanjutan yang lebih intensif untuk menentukan faktor yang mempengaruhi keanekaragaman di Sungai Batang Pelepat. Untuk menjaga kelestariannya maka perlu adanya sosialisasi melibatkan masyarakat dari lembaga konservasi, lembaga pendidikan dan pemerintah setempat mengenai pentingnya sungai Batang Pelepat terhadap satwa didalamnya khususnya ikan.

Barat (Skripsi). Bogor: Institut Pertanian Bogor.

Hui, T. H. (2009). Rasbora patrickyapi, a new species of cyprinid fish from Central Kalimantan, Borneo. The Raffles Bulletin of Zoology, 57(2), 505-509.

Hidayati, T., Sari, T. E. Y., \& Usman, U. (2015). Physical and Chemical Characteristics of Rawai Area in Bantan Tengah Village Bantan District Bengkalis Regency (Doctoral dissertation, Riau University).

Indra Mahyudi, S., Kamal, M. M., \& Sukmono, T. (2017). The Structure Community of Ichthyofauna in the Region 
Buffer Resorts Suo-Suo of Bukit Tigapuluh National Park, Indonesia.

Kasmawati, K., Hertati, R., \& Djunaidi, D. (2018). Studi Identifikasi Dan Keanekaragaman Jenis Ikan Yang Tertangkap Di Perairan Dam Betuk Kecamatan Tabir Lintas Kabupaten Merangin. SEMAH Jurnal Pengelolaan Sumberdaya Perairan, 2(3).

Kottelat, M., \& Whitten, T. (1996). Freshwater fishes of Western Indonesia and Sulawesi: additions and corrections. Hong Kong: Periplus Editions.. Kholis, M. N., \& Wahju, R. I. (2018). Struktur Ukuran Dan Hubungan Panjang Berat Ikan Kurau Di Pulau Bengkalis. ALBACORE, 2(2).

Koesbiono, 1989. Dasar-Dasar Ekologi Umum. IPB. Bogor

Kottelat, M., Whitten, A. J., Kartikasari, S. N., \& Wirjoatmodjo, S. (1993). Ikan air tawar Indonesia bagian barat dan Sulawesi. Periplus, Hongkong, 293.

Magurran, A. E. (1988). Ecological diversity and its measurement. Princeton university press.

Magurran, A. E. (2013). Measuring biological diversity. John Wiley \& Sons.

Maryono, A. (2005). Eko-hidraulika Pembangunan Sungai. Edisi Kedua. Universitas Gajah Mada, Yogyakarta.

Odum, E. P. (1996). Dasar-dasar ekologi edisi ketiga. Yogyakarta.

Preniti, R., Syafrialdi, S., \& Djunaidi, D. (2019). Studi Keanekaragaman Ikan Yang Tertangkap Menggunakan Atribut Rumpon Berbeda di
Sungai Mentenang Kabupaten Merangin. SEMAH Jurnal Pengelolaan Sumberdaya Perairan, 3(1).

Sagala, M. M., Patana, P., \& Desrita, D. (2015). Keanekaragaman Ikan di Sungai Belumai Kabupaten Deli Serdang Diversity Of Fish In Belumai River, Deli Serdang District. AQUACOASTMARINE, 3(1), 11.

Wahyuni, T. T., \& Zakaria, A. (2018). Keanekaragaman Ikan di Sungai Luk Ulo Kabupaten Kebumen. Majalah Ilmiah Biologi BIOSFERA: A Scientific Journal, 35(1), 2328.

Yazwar, 2008. Keanekaragaman Plankton dan Keterkaitannya dengan Kualitas Air di Parapat Danau Toba (Doctoral dissertation, Tesis]. Sekolah Pascasarjana. Universitas Sumatra Utara, Medan. 84 hlm).

Zahid, A., \& Rahardjo, M. F. (2008). Komposisi dan strategi pola makanan ikan ilat-ilat Cynoglossus bilineatus (Lac.)(Pisces: Cynoglossidae) di perairan Pantai Mayangan, Jawa Barat. In Prosiding Seminar Nasional Hasil-Hasil Penelitian Perikanan dan Kelautan. Jurusan Perikanan Fakultas Pertanian Uni-versitas Gadjah Mada. M (Vol. 8, pp. 1-11). 